\title{
TINJAUAN KUAT TEKAN BETON TERHADAP APLIKASI BAHAN ADITIF PLASTIMENT VZ DENGAN VARIASI DOSIS 0,15\%; 0,20\%; 0,25\% DARI BERAT SEMEN (STUDI KASUS PROYEK “GEOTECHNICAL IMPROVEMENT AT PEMPING GAS STATION)
}

\author{
Aria Alhadi \\ Dosen Tetap Prodi Teknik Sipil, Fakultas Teknik Universitas Riau Kepulauan-Batam
}

\begin{abstract}
Abstrak
Penelitian ini bertujuan untuk memperoleh persentase dosis aditif optimum. Jenis aditif yang digunakan berupa retarder dan plastisicer merk Plastiment-VZ produk Sika Indonesia. Variasi dosis yang akan dicoba yaitu 0,15\%;0,20\%; 0,25\% terhadap berat semen. Jumlah total benda uji yaitu 12 buah, dengan rincian jumlah sampel untuk setiap variasi dosis terdapat 3 benda uji dan ditambah 3 benda uji beton normal.

Benda uji yang digunakan dalam penelitian ini adalah benda uji silinder dengan ukuran diameter $150 \mathrm{~mm}$ dan tinggi $300 \mathrm{~mm}$. Benda ujii beton normal dengan variasi dosis bahan aditif direncanakan pada kuat tekan rencana $K-250$ (menggunakan rencana campuran metode American Concrete Institutes) .

Hasil penelitian menunjukkan bahwa dosis optimum dicapai pada dosis aditif terendah $(0,15 \%)$ dengan kuat tekan yang dicapai $321,88 \mathrm{~kg} / \mathrm{cm}^{2}$ dan nilai slump sebesar155 mm. Nilai slump meningkat seiring bertambahnya dosis, pada variasi beton dengan dosis aditif 0,20\% diperoleh nilai slump $160 \mathrm{~mm}$, dan untuk dosis 0,25\% diperoleh nilai slump $165 \mathrm{~mm}$. Meningkatnya nilai slump tidak berbanding lurus dengan nilai kuat tekannya. Untuk beton variasi dosis 0,20\% dicapai kuat tekan $311,83 \mathrm{~kg} / \mathrm{cm}^{2}$, dna pada dosis 0,25\% dicapai kuat tekan $306,30 \mathrm{~kg} / \mathrm{cm}^{2}$.
\end{abstract}

Kata Kunci : Aditif, Retarder, Plastisicer, Dosis Optimum

\section{PENDAHULUAN}

Pekerjaan pembuatan material beton untuk tiang bor (bored pile) merupakan bagian dari kegiatan pekerjaan tiang bor (bored pile). Untuk itu dibutuhkan kejelian dari pelaksana (kontraktor) untuk mengenali kendala, situasi maupun ketersedian peralatan kerja yang ada.

Mengacu data teknis perencanaan proyek "Geotechnical Improvement at Pemping Gas Station" yang direncanakan oleh konsultan perencana (LAPI -ITB). Disyaratkan bahwa mutu beton minimal yaitu K-250 (karakteristik beton $250 \mathrm{~kg} / \mathrm{cm}^{2}$, dengan benda uji kubus $15 \mathrm{~cm} \times 15 \mathrm{~cm} \times 15 \mathrm{~cm})$.

Sedangkan nilai slump yang direncanakan untuk tiang bor dengan sistem pengecoran menggunakan pipa tremie yaitu minimal $150 \mathrm{~mm}$ (Table 3, Slump Detail For in Concrete Use in Bored Pile Construction, BS 8004: 1986).

Dari sisi sequence kegiatan konstruksi untuk mengatasi medan yang terjal (detail pada Gambar 1. ) maka dibutuhkan waktu penuangan beton yang lebih lama dari waktu setting beton normal, yaitu dibuthkan waktu $4-6$ jam agar pengecoran kontinu untuk tiap titik tiang yang akan dituangi beton segar. 


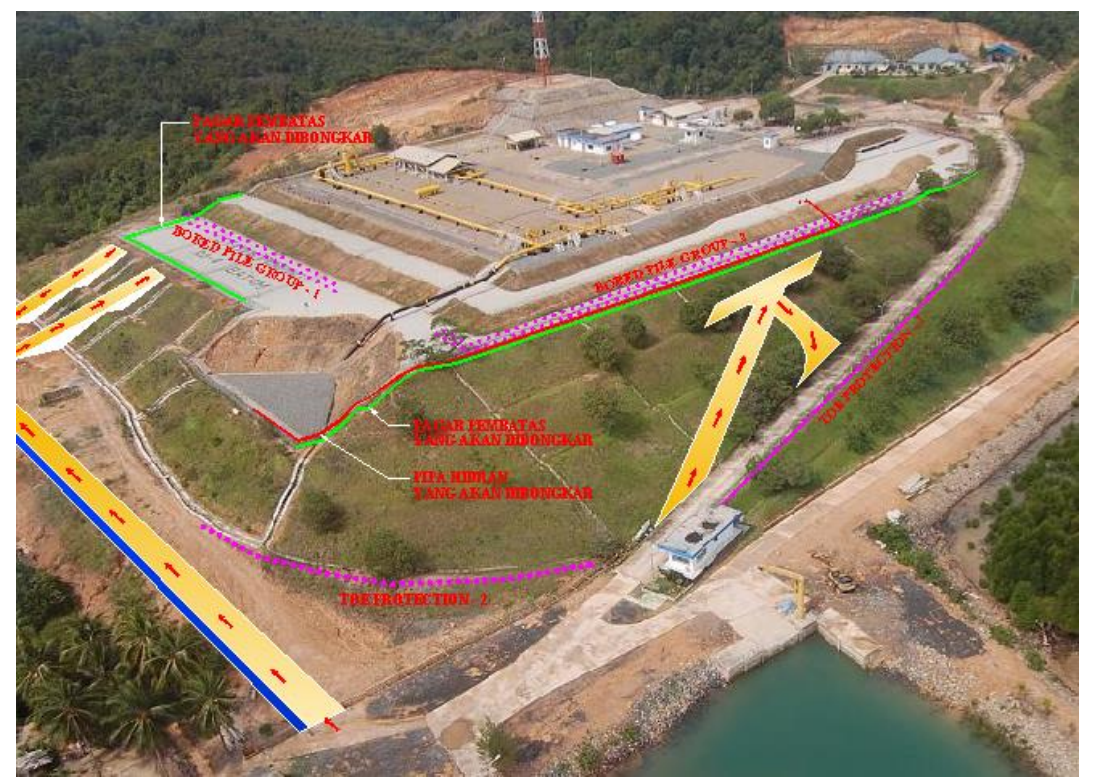

Gambar 1. Area Pengecoran Tiang Bor

Sumber : Foto Udara Dokumentasi Proyek

Untuk memenuhi kriteria mutu yang disyaratkan maka perlu direncankan komposisi campuran beton (mix design) yang akan diaplikasikan sesuai dengan kondisi dilapangan. Pada penelitian ini akan digunakan perencanaan campuran beton dengan metode ACI (American Concrete Institute) dengan menambahkan bahan aditif jenis retarder (berfungsi menghambat waktu pengikatan beton) dan plasticiser (berfungsi untuk meningkatkan kelecakan beton) pada komposisi beton yang direncanakan.

Bahan aditif Plastiment VZ produk Sika memiliki kedua fungsi tersebut, maka agar didapat dosis yang optimal perlu ditinjau pengaruh kuat tekan beton terhadap dosis yang disarankan oleh produsen aditif tersebut, mengacu pada (Technical Data Shee, Edition 3, 2009 Plastiment VZ) produsen menyarankan penggunaan aditif tersebut pada range $0,15 \%$ - 0,40 \% dari berat semen. Berdasarkan hasil diskusi dan survey pada proyek yang menggunakan aditif serupa, sebagian besar menggunakan dosis aditif kurang dari $0,20 \%$ dari berat semen.

\section{METODE PENELITIAN}

\section{Bahan Penyusun Beton}

\section{Semen}

Pada penelitian ini digunakan semen dengan merk Holcim dengan kemasan zak $\pm 40 \mathrm{~kg}$, dengan kondisi baik, hal ini dilihat secara visual tidak ada bagian dari semen tersebut yang mengeras.

2. Agregat Kasar 
Agregat kasar/granite pada pengujian ini diambil dari material yang telah ada dilapangan Pulau Pemping yang berasal dari Pulau Karimun

Bentuk agregat kasar dapat dilihat pada Gambar 2. dan Gambar 3. dibawah
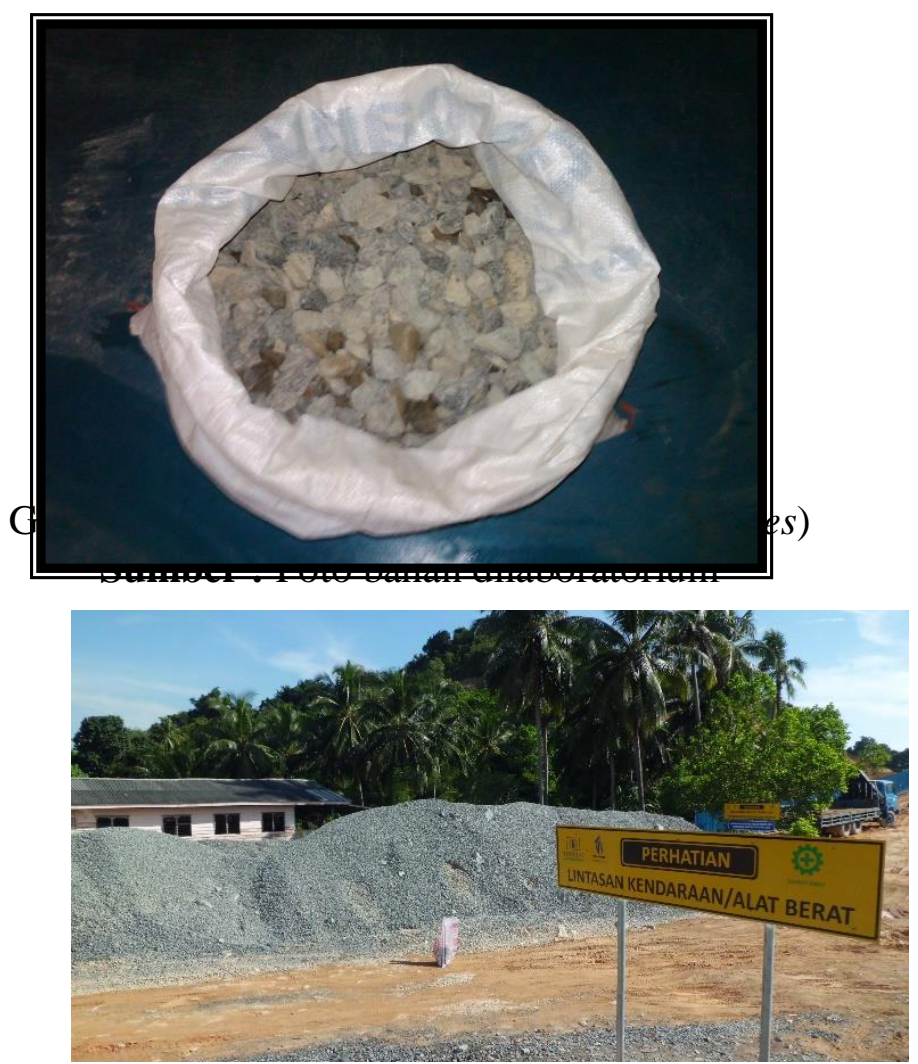

Gambar 3. Agregat Kasar Batu Pecah (granites)

Sumber : Foto Agregat Kasar dilapangan

3. Agregat

Halus

Agregat halus pada pengujian ini diambil dari material yang telah ada dilapangan Pulau Pemping yang berasal dari Pulau Moro

Bentuk

pada Gambar 4.

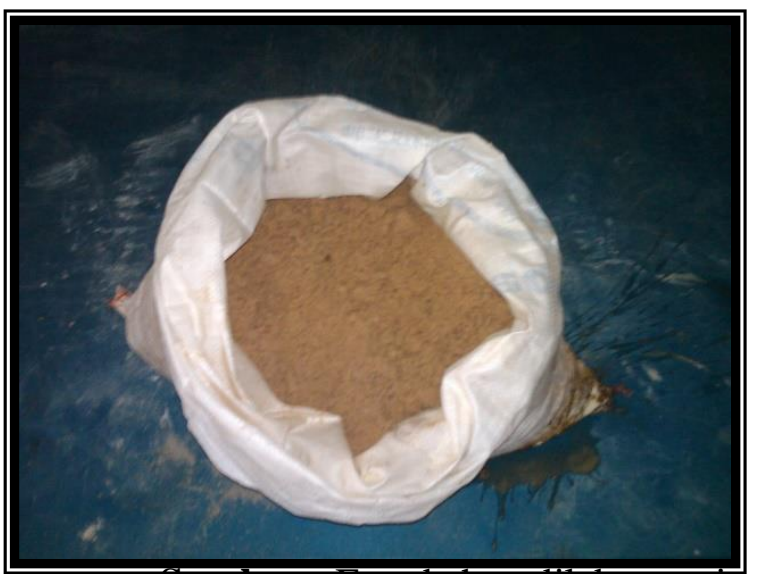

agregat halus dapat dilihat dan Gambar 5. dibawah

Sumber : Foto bahan dilaboratorium

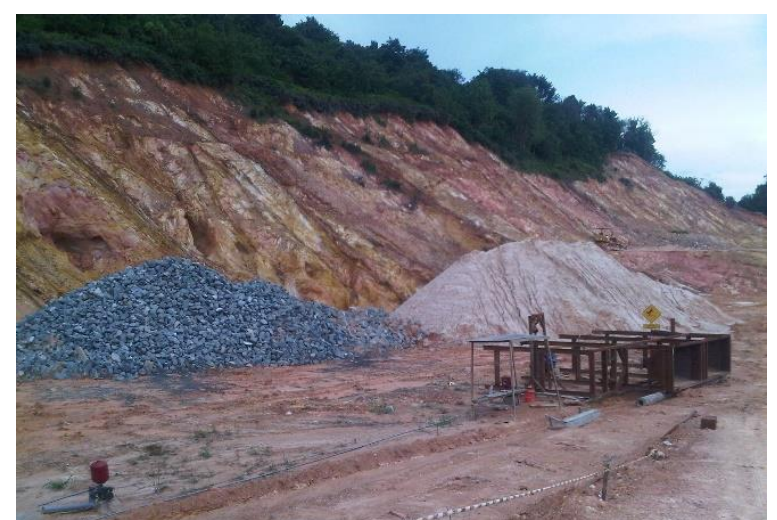


Gambar 5. Pasir /Agregat Halus

4. Air

Air yang digunakan pada penelitian berasal dari jaringan air bersih Laboratorium Bahan dan Struktur Jurusan Teknik Sipil Fakultas Teknik Universitas Internasional Batam

5. Bahan tambah/Admixtures

Retarder/plasticer yang dipakai untuk penelitian ini digunakan Plastiment - VZ produk Sika Indonesia.

\section{Rencana Campuran (Mix Design)}

Dari data hasil pengujian bahan penyusun beton dilaboratoium bahan dan kuat tekan rencana (K-250, benda uji kubus $15 \mathrm{~cm}$ x $15 \mathrm{~cm}$ x $15 \mathrm{~cm}$ ) ekivalen 20,75 MPa (benda uji silinder diameter $15 \mathrm{~cm}$ dan tinggi $30 \mathrm{~cm}$ )), maka hasil perencanaan campuran dengan metode ACI disusun pada Tabel 1 berikut :

Tabel 1. Komposisi Bahan Penyusun Beton K-250 dengan Metode ACI

\begin{tabular}{|c|c|c|c|}
\hline & $\begin{array}{l}\text { ACI "AMERICAN } \\
\text { INSTITUTE" }\end{array}$ & & \\
\hline \multirow[t]{4}{*}{1} & Kuat Tekan yang Disyaratkan & 20,75 & $\mathrm{MPa}$ \\
\hline & Umur beton & 28 & hari \\
\hline & Volume Pekerjaan & Sedang & \\
\hline & Mutu Pekerjaan & Baik & \\
\hline 2 & Standar Deviasi & 4 & \\
\hline 3 & Kuat Tekan rata-rata & 27,31 & $\mathrm{MPa}$ \\
\hline 4 & F a s Berdasarkan Kuat Tekan (umur beton 28 hari) & 0,531 & \\
\hline 4 & F a s berdasarkan Keawetan \& Lingkungan & 0,6 & \\
\hline 5 & dipilih yang terendah & 0,531 & \\
\hline 6 & Volume Udara & $1 \%$ & \\
\hline \multirow[t]{4}{*}{7} & Berdasarkan Jenis Struktur & & \\
\hline & Nilai Slam & $75-150$ & $\mathrm{~mm}$ \\
\hline & Ukuran Maksimum agregat & 40 & $\mathrm{~mm}$ \\
\hline & Jumlah Air yang diperlukan & 177 & liter \\
\hline 9 & Jumlah Semen & 0,334 & ton \\
\hline \multirow[t]{4}{*}{10} & Modulus Halus Butir Pasir & 2,602 & \\
\hline & Berat Jenis Pasir & 2,578 & \\
\hline & Berat Jenis Kerikil & 2,601 & \\
\hline & Berat Satuan Kerikil & 1,497 & \\
\hline \multirow[t]{2}{*}{11} & Volume Kerikil (Agr. Kasar) & 0,72 & \\
\hline & Berat Kerikil & 1,078 & \\
\hline & \multicolumn{3}{|l|}{$\begin{array}{l}\text { Kebutuhan Bahan } \\
\text { Berat beton satuan }\left(\mathrm{kg} / \mathrm{m}^{\wedge} 3\right)\end{array}$} \\
\hline & Air & 177,00 & $\mathrm{~kg}$ \\
\hline & Semen & 333,51 & $\mathrm{~kg}$ \\
\hline & Pasir & 754,30 & $\mathrm{~kg}$ \\
\hline & Kerikil & 1078,20 & $\mathrm{~kg}$ \\
\hline
\end{tabular}




\begin{tabular}{|c|c|c|c|c|c|c|c|}
\hline \multirow[t]{2}{*}{ No } & $\begin{array}{l}\text { Jenis } \\
\text { Campuran }\end{array}$ & \multirow{2}{*}{$\begin{array}{l}\text { Brt } \\
\text { Semen } \\
\text { Kg } \\
\end{array}$} & \multirow{2}{*}{$\begin{array}{l}\text { Brt } \\
\text { Pasir } \\
\text { Kg } \\
\end{array}$} & \multirow{2}{*}{$\begin{array}{ll}\text { Brt } & \text { Batu } \\
\text { Pecah } & \\
\text { Kg } & \\
\end{array}$} & \multirow{2}{*}{$\begin{array}{l}\text { Juml } \\
\text { Air } \\
\text { Liter } \\
\end{array}$} & \multirow{2}{*}{$\begin{array}{l}\text { Brt } \\
\text { Aditif } \\
\text { gram }\end{array}$} & \multirow[t]{2}{*}{ Keterangan } \\
\hline & Beton & & & & & & \\
\hline 1 & Normal & 333,5 & 754,5 & 1078,0 & 177,0 & 0,0 & - \\
\hline 2 & $\mathrm{r}$ dosis 1 & 333,5 & 754,5 & 1078,0 & 177,0 & 500,3 & $\begin{array}{l}\text { Sika } \\
\text { VZ }\end{array}$ \\
\hline 3 & $\begin{array}{l}\text { Retarder dosis } 2 \\
(0,20 \%)\end{array}$ & 333,5 & 754,5 & 1078,0 & 177,0 & 667,0 & Plastiment \\
\hline 4 & $\begin{array}{l}\text { Retarder dosis } 3 \\
(0,25 \%)\end{array}$ & 333,5 & 754,5 & 1078,0 & 177,0 & 833,8 & Plastiment \\
\hline
\end{tabular}

\begin{tabular}{l} 
Berat Beton \\
\begin{tabular}{|l|l|l||}
\hline Berat satu adukan beton, (3 Mould + 20\%) & 2343,01 & $\mathrm{~kg} / \mathrm{m}^{\wedge} 3$ \\
\hline Air & 0,02 & \multicolumn{1}{|c||}{$\mathrm{m}^{\wedge} 3$} \\
\hline Semen & 3,54 & $\mathrm{~kg}$ \\
\hline Pasir & 6,67 & $\mathrm{~kg}$ \\
\hline Kerikil & 15,09 & $\mathrm{~kg}$ \\
\hline Berat Beton & 21,56 & $\mathrm{~kg}$ \\
\hline
\end{tabular} \\
\hline
\end{tabular}

Sumber : Hasil Perhitungan Kompossii Bahan Penyusun Beton K-250

Variasi penggunaan aditif pada benda uji disajikan oleh Tabel 2 berikut:

Tabel 2. Komposisi Variasi Dosisi Aditif terhadap Campuran Beton

\section{Pengujian Bahan}

1. Pengujiaan gradasi agregat (gradasi)

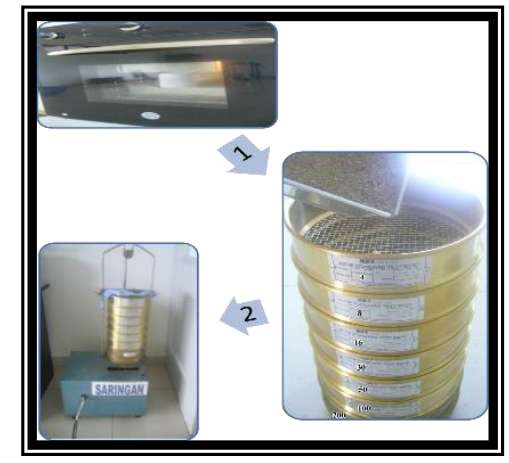

Gambar 6. Skema Pemeriksaan Gradasi Agregat Sumber : Foto dilaboratorium 
2. Pengujian berat jenis dan penyerapan agregat

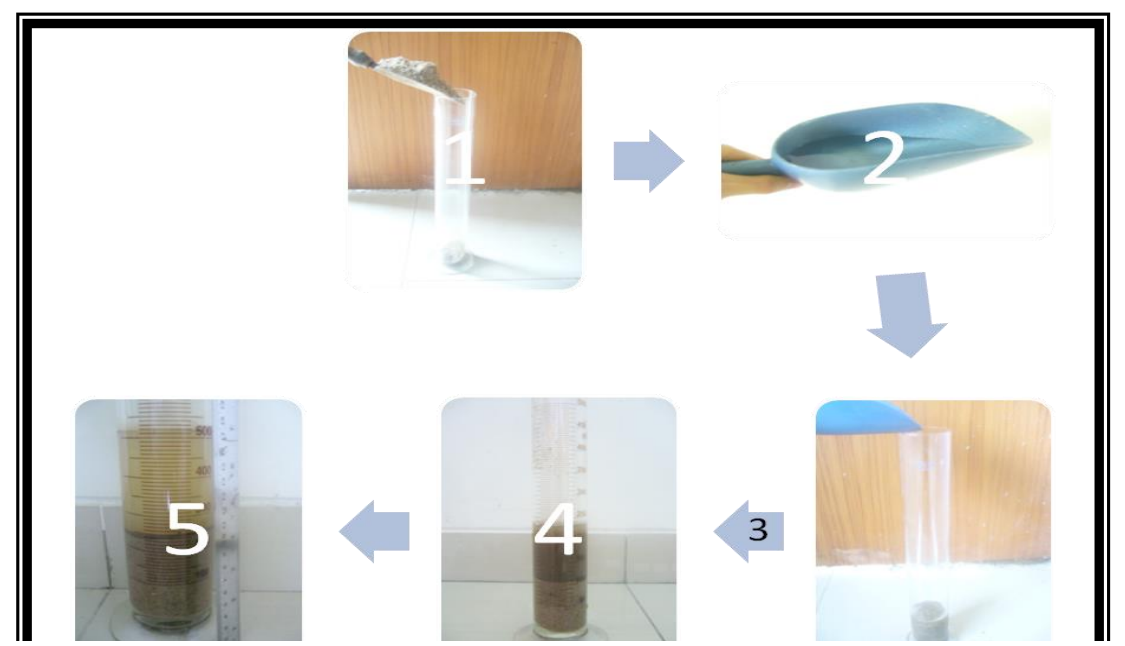

Pembuatan

Gambar 8. Skema Pemeriksaan Kandungan Bahan Organik

Sumber : Foto dilaboratorium

\section{Benda Uji Pendahuluan}

Pada tahap ini dimaksudkan untuk mencermati karakteristik perilaku campuran khususnya mengenai kendala-kendala yang akan dialami pada proses pelaksanaanya. Hal tersebut juga harus diantisipasi dengan tindakan-tindakan tertentu sehingga hasil perencanaan dapat dipastikan mampu diterapkan dilapangan.

\section{Pembuatan Benda Uji}

Urutan pelaksanaan pembuatan benda uji dilakukan sebagai berikut.

1. Menyiapkan cetakan yang telah dibersihkan dan semua permukaan dilapisi dengan tipis dengan oli dengan pada moulding benda uji bagian pada permukaannya, hal ini dimaksudkan agar pada saat pelepasan cetakan benda uji tidak mengalami cacat pada bagian permukaannya,

2. Mencampur semen dan pasir sampai dengan material tersebut bersifat homogen sesuai dengan perhitungan pada Tabel 1 dan Tabel 2,

3. Setelah material tersebut homogen maka tambahakan batu pecah (granites) aduk kembali sampai dengan material penyusun beton tersebut kembali homogen antara agregat (pasir dan batu pecah) dan semen,

4. Menambahkan air sesuai dengan ukuran yang direncanakan serta mengaduk kembali sampai dengan kondisi beton segar tersebut homogen.

5. Mengukur nilai slump sesuai dengan prosedur standar pengukuran slump

6. Mengisi cetakan/moulding dan memberikan pemadatan yang cukup sesuai dengan jumlah yang direncanakan

\section{Perawatan Benda Uji}

Perawatan benda uji dilakukan agar proses hidrasi semen (reaksi semen dan air) berlangsung dengan sempurna kira-kira selama 28 hari. Kelembaban pada permukaan beton 
dijaga dengan cara menutup semua sampel beton dengan karung basah, yang disiram secara teratur setiap hari. Hal ini dimaksudkan agar air di dalam beton diharapkan tidak menguap keluar akibat perbedaan suhu akibat proses hidrasi semen maupun suhu ruang. Hal tersebut dilakukan di Laboratorim Struktur dan Bahan Jurusan Teknik Sipil Fakultas Teknik Universitas Internasional Batam, Kepri.

\section{Pelaksanaan Pengujian}

Pelaksanaan pengujian dilaksanakan setelah mencapai umur 3 hari untuk beton normal dan 4 hari pada beton yang menggunakan aditif ( 1 hari diasumsikan waktu jedah masa setting beton akibat penggunaan retarder). Pengujian kuat tekan beton dilakukan di Laboratorium Struktur dan Bahan milik PT Citra Lautan Teduh, Batu Besar Batam-Kepulauan Riau.

Urutan pengujian kuat tekan beton adalah sebagai berikut.

a. Silinder beton yang telah berumur lebih dari 3 (tiga) hari ditimbang serta diukur diameter dan tingginya.

b. Pada saat pengujian, benda uji diletakkan pada alas pembebanan mesin uji kuat tekan beton.

c. Mesin uji kuat tekan dihidupkan serta dilakukan setting pada besarnya pertambahan pembebanan/hal ini dilakukan karena benda uji yang akan diuji memiliki dimensi(diameter $15 \mathrm{~cm}$ dan tinggi $30 \mathrm{~cm}$ ).

\section{Pengumpulan dan Analisa Data}

a. Kuat tekan beton ( $\mathrm{f}^{\prime} \mathrm{c}$ )

Nilai kuat tekan beton ( $\sigma$ tekan ) diperoleh dari beban maksimum $(\mathrm{P})$ dibagi luas penampang silinder (A), yang persamaannya seperti pada Persamaan 1. berikut

$\sigma=\frac{P}{A}$ .1 Pengujian

dilaksanakan pada umur lebih dari 3 hari pada beton normal, dan 4 hari pada beton yang menggunakan aditif.

b. Hubungan umur beton dan kuat tekan beton

Pada gambar dibawah dapat perkembangan kuat beton berdasarkan umurnya.(digunakan untuk mengkonversi nilai kuat tekan beton berdasarkan umur beton).

\section{HASIL DAN PI MBISASASAN}

Gambar 9. Hubungan umur beton dan kuat tekannnya

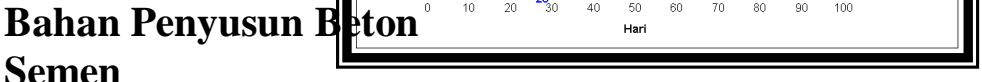

Semen yang digunakan merupakan semen Holcim tipe I (OPC ordinary portland cement)yang umum dipakai, dalam penelitian ini produk semen yang digunakan yaitu semen Holcim dalam kemasan $40 \mathrm{~kg}$ per zak dengan kondisi butir-butir semen halus dan tidak menggumpal sehingga dapat digunakan sebagai bahan campuran beton.

Air 
Air yang digunakan pada penelitian berasal dari jaringan air bersih Adhya Tirta Batam (ATB). Kondisi air dalam keadaan jernih, tidak berwarna, tidak berbau dan memenuhi syarat sebagai air minum, sehingga memenuhi syarat sebagai bahan campuran beton.

\section{Agregat Halus}

Dari hasil pengujian bahan hasil pemeriksaan pasir beton (berasal dari Pulau Moro) didapatkan hasil sebagai berikut:
Berat jenis
(SSD)
: 2,578
Persentase penyerapan air
$: 1,42 \%$
Modulus Halus Butir (MHB) : 2,6
Kandungan zat organik
: Tidak ada zat organik ( $\mathrm{NaOH}$ kuning muda)

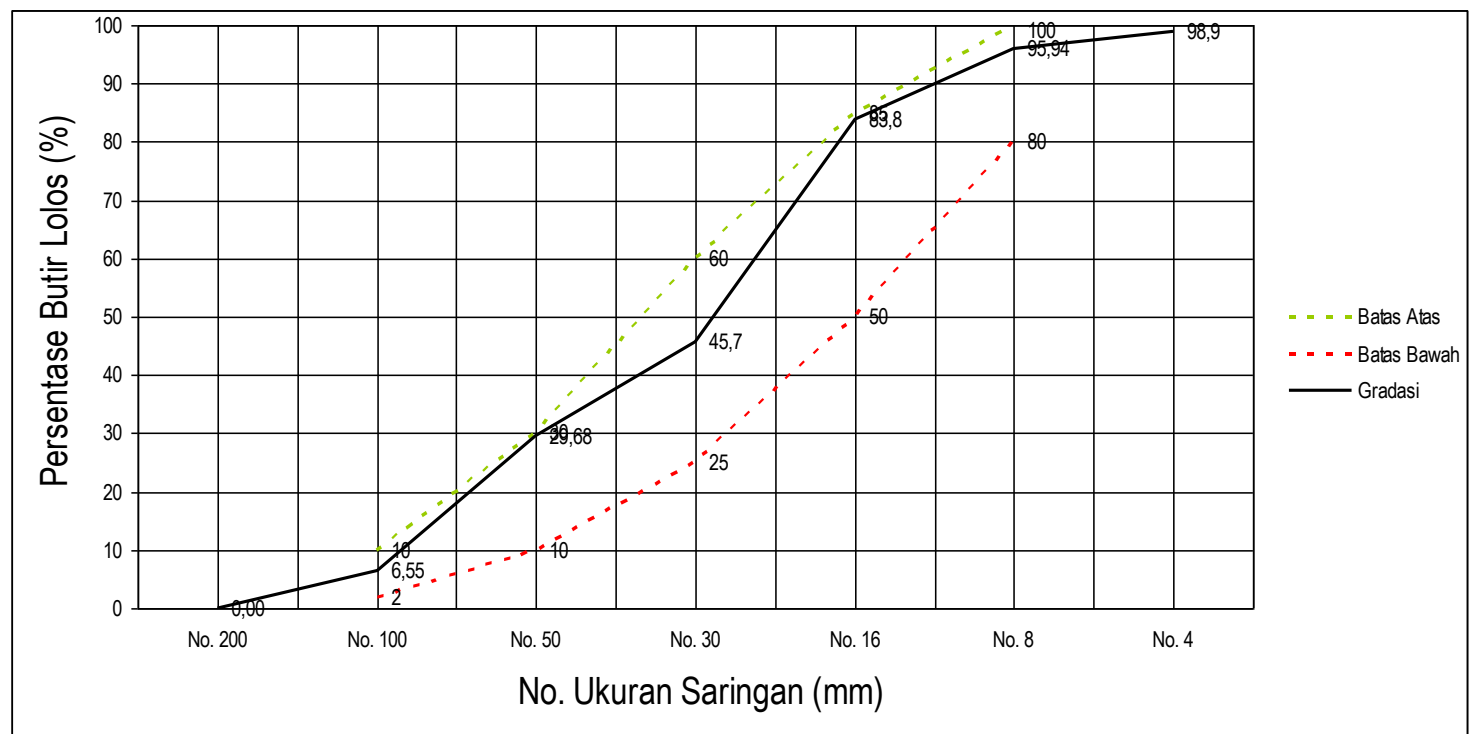

Gradasi

: Baik (lihat Gambar 10.)

Gambar 10. Kurva Batas Gradasi Agregat Halus

Nilai MHB berkisar diantara 1,5 sampai 3,8. (mengacu SNI 03-2494-2002/ASTM C 637-90), sehingga agregat halus dapat digunakan.

\section{Agregat Kasar (Kerikil)}

Dari pemeriksaan bahan di laboratorium agregat kasar didapatkan hasil sebagai berikut:

Berat Jenis (SSD) : 2,6

Persentase penyerapan air : $0,3 \%$

Modulus halus butir (MHB) : 6,81

Berat isi

: 1,41

Gradasi

: Baik (lihat Gambar 11) dengan diameter maksimum $40 \mathrm{~mm}$ ) 
Sehingga

agregat kasar dapat

Gambar 11. Kurva Batas Gradasi Agregat Kasar

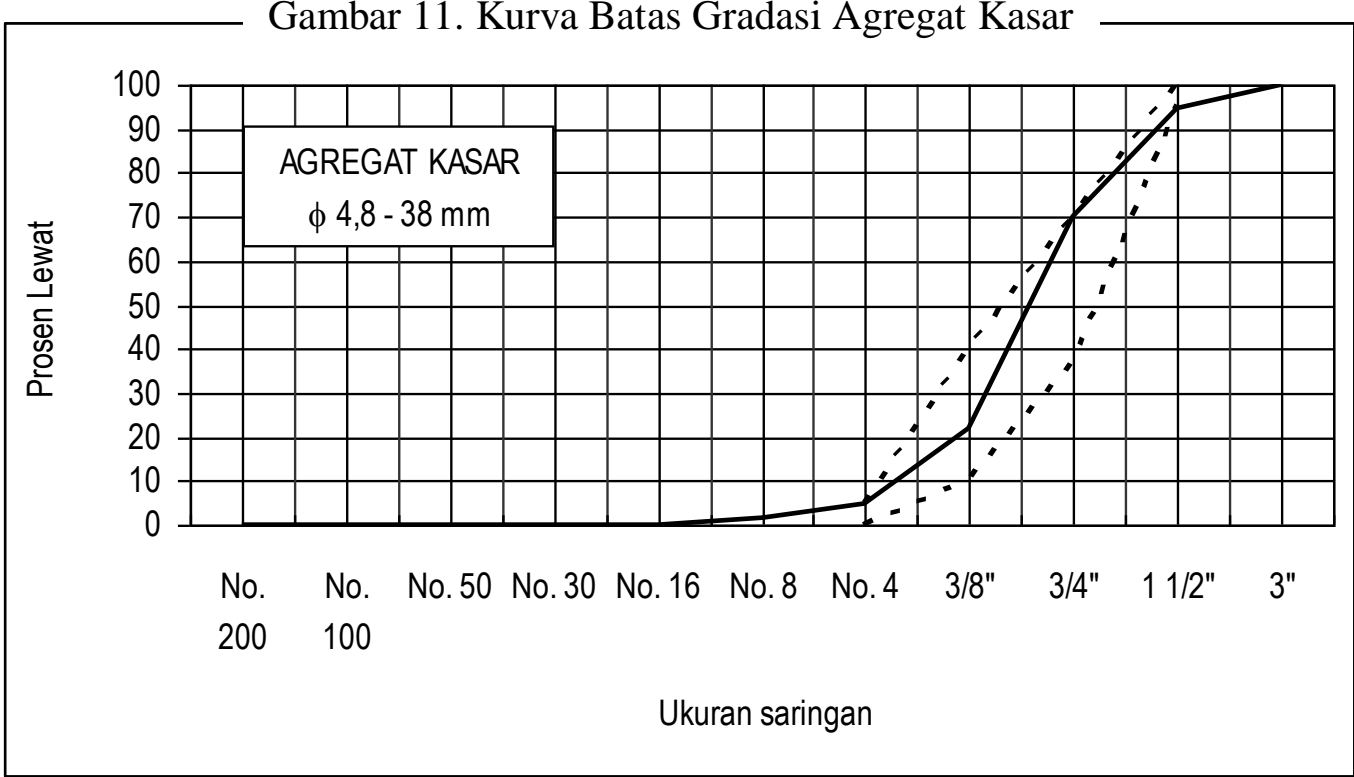

digunakan sebagai bahan susun beton .

\section{Pengujian Silinder Beton}

Dari nilai kuat tekan proyeksi untuk kuat tekan beton pada Tabel 3. maka nilai kuat tekan karakteristik yang dicapai masih jauh lebih tinggi dibanding kuat tekan yang disyaratkan yaitu K-250. Maka dapat disimpulkan bahwa komposisi campuran beton rencana dapat digunakan.

\begin{tabular}{|c|c|c|c|c|}
\hline No & Jenis Campuran & $\begin{array}{l}\text { Kuat tekan } \\
\text { rata-rata } \\
\text { umur } 3 \text { hari } \\
\left(\mathrm{Kg} / \mathrm{cm}^{2}\right)\end{array}$ & $\begin{array}{l}\text { Kuat tekan } \\
\text { proyeksi } \\
\text { umur 28 hari } \\
\left(\mathrm{Kg} / \mathrm{cm}^{2}\right)\end{array}$ & $\begin{array}{l}\text { Kuat tekan } \\
\text { Koreksi bentuk } \\
\text { Silinder ke Kubus }\end{array}$ \\
\hline & & $\mathrm{a}$ & $\mathrm{b}=\mathrm{a} \times(1 / 0,46)$ & $\mathrm{c}=\mathrm{b} \times(1 / 0,83)$ \\
\hline 1 & Beton Normal & 120,217 & 261,3405797 & 314,8681683 \\
\hline 2 & $\begin{array}{ll}\text { Beton } & \text { dengan } \\
\text { retarder VZ } & 0,15 \%\end{array}$ & 122,897 & 267,1666667 & 321,8875502 \\
\hline 3 & $\begin{array}{ll}\text { Beton } & \text { dengan } \\
\text { retarder VZ } & 0,20 \%\end{array}$ & 119,060 & 258,826087 & 311,838659 \\
\hline
\end{tabular}




\begin{tabular}{|c|c|c|c|c|c|c|c|c|c|c|}
\hline No & $\begin{array}{l}\text { Tgl Cetak } \\
\text { Beton }\end{array}$ & $\begin{array}{l}\text { Waktu } \\
\text { Curing }\end{array}$ & $\begin{array}{l}\text { Tanggal } \\
\text { Pengujian }\end{array}$ & $\begin{array}{l}\text { Brt } \\
\text { Spesimen } \\
\text { Kg }\end{array}$ & $\begin{array}{l}\text { Densitas } \\
\mathbf{t} / \mathbf{m}^{3}\end{array}$ & $\begin{array}{l}\text { Nilai } \\
\text { Slump } \\
\text { cm } \\
\end{array}$ & $\begin{array}{l}\text { Beban } \\
\text { Max. } \\
\text { KN } \\
\end{array}$ & $\begin{array}{l}\text { Kuat Te } \\
\text { N/mm }\end{array}$ & $\begin{array}{l}\text { kan } \\
\mathrm{Kg} / \mathrm{cm}^{2}\end{array}$ & Keterangan \\
\hline 1 & $31 / 03 / 2012$ & 3 hari & 03/04/2012 & 12,28 & 2,32 & 12,00 & 210 & 11,88 & 121,18 & $\begin{array}{l}\text { Beton } \\
\text { Normal }\end{array}$ \\
\hline 2 & $31 / 03 / 2012$ & 3 hari & 03/04/2012 & 12,08 & 2,28 & 12,50 & 225 & 12,73 & 129,83 & $\begin{array}{l}\text { Beton } \\
\text { Normal }\end{array}$ \\
\hline 3 & $31 / 03 / 2012$ & 3 hari & 03/04/2012 & 12,04 & 2,27 & 12,00 & 190 & 10,75 & 109,64 & $\begin{array}{l}\text { Beton } \\
\text { Normal }\end{array}$ \\
\hline \multicolumn{4}{|c|}{ Nilai rata-rata } & 12,13 & 2,29 & 12,17 & 208,33 & 11,79 & 120,22 & $\begin{array}{l}\text { Beton } \\
\text { Normal }\end{array}$ \\
\hline $1 \mathrm{~A}$ & $06 / 04 / 2012$ & 4 hari & $10 / 04 / 2012$ & 12,32 & 2,32 & 15,50 & 218 & 12,34 & 125,79 & VZ 0,15\% \\
\hline $2 \mathrm{~A}$ & $06 / 04 / 2012$ & 4 hari & $10 / 04 / 2012$ & 12,29 & 2,32 & 15,50 & 209 & 11,83 & 120,6 & VZ $0,15 \%$ \\
\hline $3 \mathrm{~A}$ & $06 / 04 / 2012$ & 4 hari & $10 / 04 / 2012$ & 12,16 & 2,29 & 15,50 & 212 & 12 & 122,3 & VZ 0,15\% \\
\hline \multicolumn{4}{|c|}{ Nilai rata-rata } & 12,26 & 2,31 & 15,50 & 213,00 & 12,06 & 122,90 & VZ 0,15\% \\
\hline & & & & & & & & & & \\
\hline $1 \mathrm{~B}$ & $06 / 04 / 2012$ & 4 hari & $10 / 04 / 2012$ & 12,14 & 2,29 & 16,00 & 210 & 11,88 & 121,18 & VZ 0,20\% \\
\hline $2 \mathrm{~B}$ & $06 / 04 / 2012$ & 4 hari & $10 / 04 / 2012$ & 12,22 & 2,31 & 16,00 & 208 & 11,77 & 120,02 & VZ 0,20\% \\
\hline $3 \mathrm{~B}$ & $06 / 04 / 2012$ & 4 hari & $10 / 04 / 2012$ & 12,18 & 2,3 & 16,00 & 201 & 11,37 & 115,98 & VZ 0,20\% \\
\hline \multicolumn{4}{|c|}{ Nilai rata-rata } & 12,18 & 2,30 & 16,00 & 206,33 & 11,67 & 119,06 & VZ 0,20\% \\
\hline & & & & & & & & & & \\
\hline $1 \mathrm{C}$ & $06 / 04 / 2012$ & 4 hari & $10 / 04 / 2012$ & 12,1 & 2,28 & 16,50 & 205 & 11,6 & 118,29 & VZ $0,25 \%$ \\
\hline $2 \mathrm{C}$ & $06 / 04 / 2012$ & 4 hari & $10 / 04 / 2012$ & 12,2 & 2,29 & 16,50 & 200 & 11,32 & 115,41 & VZ $0,25 \%$ \\
\hline $3 \mathrm{C}$ & $06 / 04 / 2012$ & 4 hari & $10 / 04 / 2012$ & 12,15 & 2,29 & 16,50 & 203 & 11,49 & 117,14 & VZ $0,25 \%$ \\
\hline \multicolumn{4}{|c|}{ Nilai rata-rata } & 12,15 & 2,29 & 16,50 & 202,67 & 11,47 & 116,95 & VZ 0,25\% \\
\hline
\end{tabular}




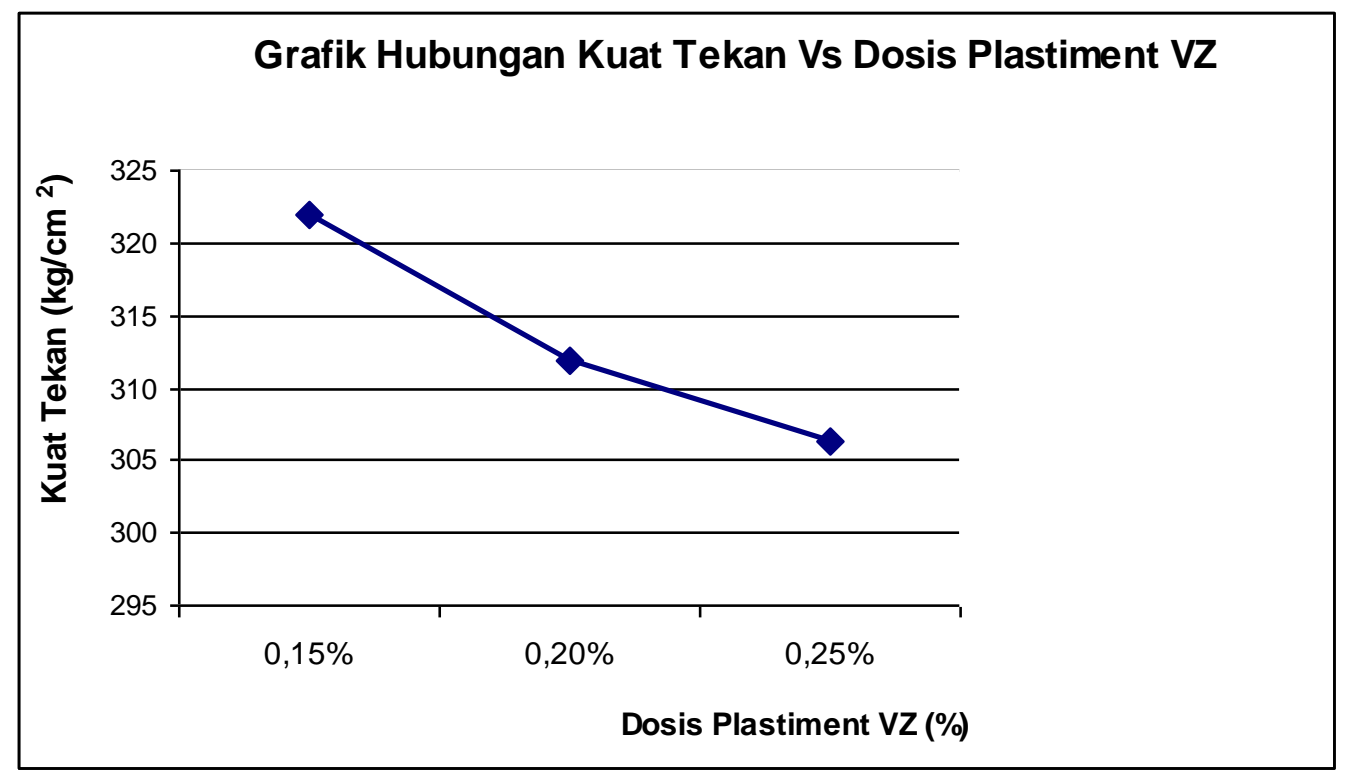

Gambar 11. Grafik Hubungan Kuat Tekan Vs Dosis Plastiment VZ

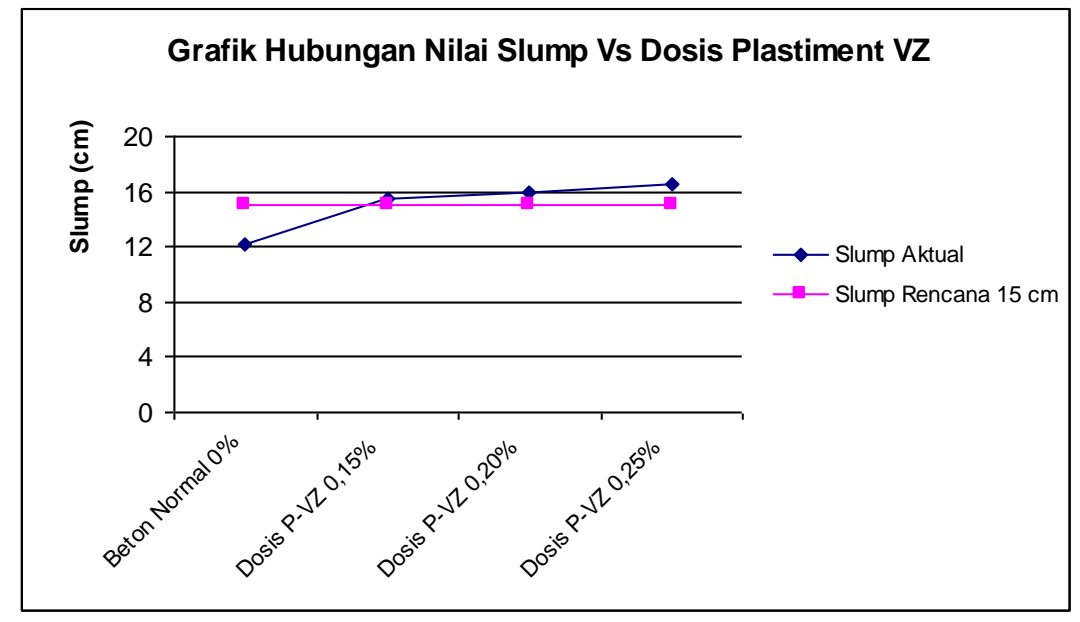

Gambar 12. Grafik Hubungan Peningkatan Kuat Tekan Vs Dosis Plastiment VZ

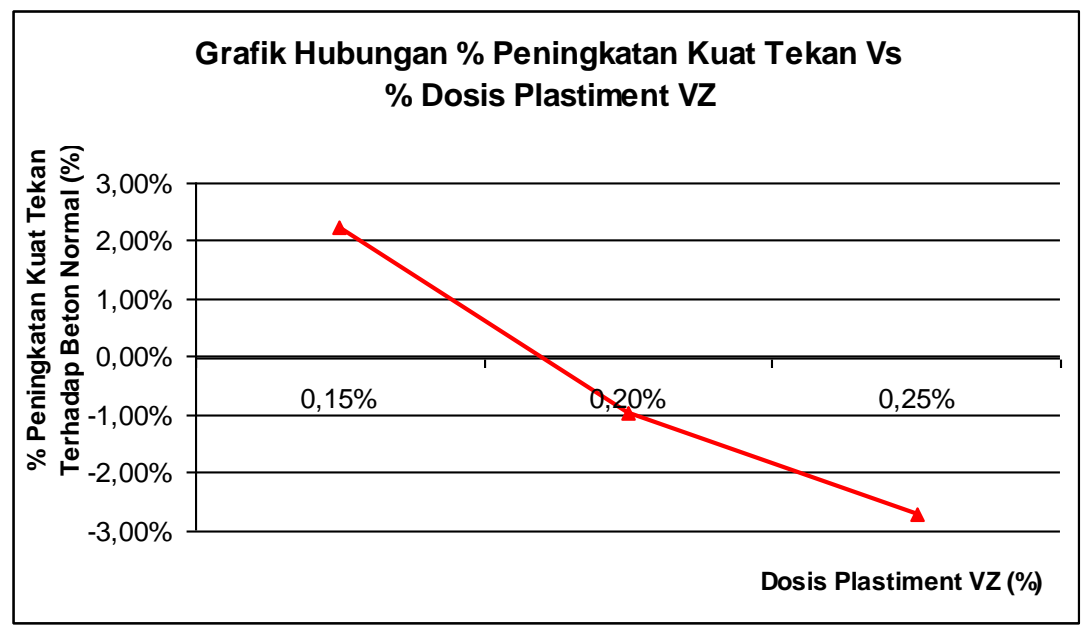




\section{Bahan Aditif Plastiment VZ}

Dari Gambar 11. dan Gambar 12. menunjukkan bahwa dengan meningkatkan dosis aditif pada beton tidak selalu berdampak meningkatkan mutunya (kuat tekan). Pada penelitian ini penurunan nilai kuat tekan beton pada dosis yang lebih tinggi disebabkan oleh terjadinya bleeding (naiknya air pada permukaan) sampelnya. Meningkatnya nilai slump seiring dengan meningkatnya dosis penggunaan aditif (lihat pada Gambar 13.), tentunya memiliki hubungan yang erat dengan penyebab bleeding pada beton.

Untuk memenuhi kriteria beton yang disyaratkan K-250 dan nilai slump $150 \mathrm{~mm}$, penggunaan aditif diperlukan, khususnya dalam hal pemenuhan persyaratan kelecakan (workability) beton, hal tersebut terlihat pada Gambar 13 bahwa nilai slump rencana pada beton normal tidak dapat terpenuhi.

\section{KESIMPULAN}

Dari penelitian ini dapat diambil beberapa kesimpulan yaitu sebagai berikut :

1. Kuat tekan beton normal sebesar $314,86 \mathrm{~kg} / \mathrm{cm}^{2}$ memenuhi kriteria yang disyaratkan (>

2. Nilai slump beton normal $12,17 \mathrm{~cm}$ tidak dapat memenuhi syarat kelecakan (workability) beton yang direncanakan $15 \mathrm{~cm}$.

3. Dosis optimum aditif Plastiment VZ yaitu $0,15 \%$ dengan nilai kuat tekan yang dicapai sebesar $321,88 \mathrm{~kg} / \mathrm{cm}^{2}$ dengan nilai slump $155 \mathrm{~mm}$, merupakan kuat tekan tertinggi dibandingkan dari dosis-dosis lainnya yaitu dosis $0,20 \%$ dengan kuat tekan $311,83 \mathrm{~kg} / \mathrm{cm}^{2}$ dengan nilai slump $160 \mathrm{~mm}$, dan dosis 0,25\% dengan kuat tekan 306,30 $\mathrm{kg} / \mathrm{cm}^{2}$ dengan nilai slump $165 \mathrm{~mm}$.

\section{DAFTAR PUSTAKA}

ACI Committee 318-08. (2008). Building Code Requirements for Structural Concrete and Commentary. Farmington Hills, Michigan: American Concrete Institute.

ASTM C-33-03. (2003). Standard Specification for Concrete Aggregates. West Conshohocken, Pennsylvania: ASTM International.

ASTM C-39/C-39M-05. (2005). Standard Test Method for Compressive Strength of Cylindrical Concrete Specimens. West Conshohocken, Pennsylvania: ASTM International.

ASTM C-150-07. (2007). Standard Specification for Portland Cement. West Conshohocken, Pennsylvania: ASTM International.

Anonim, BS 8004: 1986

Direktorat Penyelidikan Masalah Bangunan. (1981). Peraturan Pembebanan Indonesia untuk Gedung 1983. Bandung: Yayasan Lembaga Penyelidikan Masalah Bangunan.

Technical Data Sheet, Edition 3, 2009, Palstiment-VZ, Sika Indonesia

Mulyono, Tri. (2005). Teknologi Beton. Yogyakarta: Penerbit ANDI.

Wahyuni, Atik. (2008). Buku Petunjuk Teknologi Bahan Konstruksi. Batam: Laboratorium UIB. 
